УДК 303.1 : 316.334 .52

Сірий Свген Володимирович

доктор соиіологічних наук, професор, Київський національний університет імені Тараса Шевченка, Київ, Украӥна, sociol@ukr.net

\title{
РЕГІОНАЛІЗАЦІЯ УКРАЇНИ У КОНТЕКСТІ СОЦІОЛОГІЧНОГО ДОСЛІДЖЕННЯ СОЦІАЛЬНОЇ НАПРУЖЕНОСТІ
}

У матеріалі висвітлюється одна із широких методологічних проблем у розгортанні різносторонніх соціальних в соціологічних досліджень у різних предметностях українського суспільства в екстраполяції територіальногеографічного розподілу України - критерії іiі регіоналізації. У статті даються основні наукові визначення та підходи щодо розрізнення регіону. У розрізі вітчизняних умов регіональної диференційованості розглянуто різні дослідницькі підходи 3 цієї проблематики та критерії регіоналізації. Метою роботи є обгрунтування оптимального підходу та критерію регіонування в Україні в контексті дослідження соціальної напруженості. В аналізі низки наукових підходів як оптимальним пропонується політико-адміністративний розподіл регіонів у дослідженні соціальної напруженості.

Ключові слова: соціальна напруженість, регіон, регіоналізація, методика.

Siriy Yevgen, Sc. D. in Sociology, professor, Kyiv Taras Shevchenko National University, Kyiv, Ukraine

Regionalization of Ukraine in the context of the social tension sociological research

The paper analyzes one of the broadest methodological problems in the development of the diverse social and sociological studies on various subjects of the Ukrainian society in the extrapolation of the territorial and geographical distribution of Ukraine - the criteria for its regionalization. The article provides major research difinitions and approaches concerning political and administrative division of regions. In the context of domestic conditions for regional differentiation, various research approaches on this issue and regionalization criteria are considered. The aim of the work is to justify the optimal approach and criterion of Ukraine regionalization in the social tension study context. The analysis of numerous scientific approaches suggests the optimal one to be a political and administrative division of regions within the study of social tension.

Key words: social tension, region, regionalization, methodology. 


\section{РЕГІОНАЛІЗАЦІЯ УКРАЇНИ У КОНТЕКСТІ СОЦІОЛОГІЧНОГО ДОСЛІДЖЕННЯ СОЦІАЛЬНОЇ НАПРУЖЕНОСТІ}

Сирый Евгений Владимирович, доктор сочиологических наук, профессор, Киевский национальный университет имени Тараса Шевченко, Киев, Украина

\section{Регионализация Украины в контексте социологического исследования социальной напряженности}

В материале освещается одна из широких методологических проблем в развертывании разносторонних социальных и социологических исследований в различных предметностей украинского общества в экстраполяции территориально-географического распределения Украины - критерии ее регионализации. В статье даются основные научные определения и подходы к различиям региона. $\mathrm{B}$ разрезе отечественных условий региональной дифференцированности рассмотрены различные исследовательские подходы по этой проблематике и критерии регионализации. Целью работы является обоснование оптимального подхода и критерия регионирования в Украине в контексте исследования социальной напряженности. В анализе ряда научных подходов как оптимальным предлагается политико-административное деление регионов в исследовании социальной напряженности.

Ключевые слова: социальная напряженность, регион, регионализация, методика.

Вступ. Сучасна соціальна напруженість у фокусі сучасної соціологічної науки - це системне явище, на яке істотно впливають не лише макроекономічні та макросоціальні особливості суспільства. Їй властиві й інші чинники України 3 огляду на іiі природно-кліматичні, поселенські та історичні складові України. Саме тому логіка дослідження призвела до необхідності вивчення регіональних особливостей соціальної напруженості громадян. Арсенал вибудованої вимірювальної методики соціальної напруженості повинен бути спроможнім визначати рівень останньої в регіонах, в окремих соціальних групах населення регіонів, виявляти індикатори (чинники), рівень незадоволеності населення якими достатньо високий. Потенційно, це універсальний інструмент, котрий допомагає виявити особливості дії зовнішніх чинників у різних регіонах, так як їх дія на появу/зростання соціальної напруженості, з точки зору регіональних особливостей не завжди однакова. Тому, у утворювальній методиці повинні закладатися можливості визначати особливості розвитку регіонів, а отже, неоднозначність чинників, що визначають соціальну напруженість у регіонах. Напруженість 3'являється з виникненням у суспільстві певної ситуації (і не у кожному регіоні), загострюється разом з ії розвитком і спадає, коли ця ситуація вичерпує себе, зникає, змінюється на іншу. А тому, вивчення соціальної напруженості потребує і ситуаційного підходу у специфіці окремого регіону, при аналізі якого необхідно враховувати історичний, соціокультурний 
розвиток певного регіону, що виявляється у якісних процедурах аналізу даних. Саме таким чином можна зрозуміти предметність «врахування регіональних особливостей» вимірювання соціальної напруженості в Україні, котрі також, за певних обставин, можуть генерувати ії зростання.

Попереднім завданням дослідження постає також і вияв та розкриття дослідницьких проблем, в аспекті теорії і методології даного предметного напрямку. Це саме i стосується алгоритму вибудови зараховування до дослідницького арсеналу методики врахування регіональних особливостей, що становить наукову проблему даного дослідження. Відповідний аналіз засобів даної дослідницької проблематики показує, що проблемна обставина пов'язана, на наш погляд, зі слабкою експлікацією базових понять, зокрема: «регіон», «регіоналізація», 3 відсутністю чітких теоретичних моделей даного явища, 3 неопрацьованістю методологічних підходів до вимірювання напруженості саме українських реалій.

Регіон як система надає свою дію на соціальну напруженість. Тому іiі розвиток та форм ii прояву знаходяться і під впливом регіону. Причина іiі зростання і тенденція іiі розвитку в різних регіонах, на певних етапах їх розвитку $\epsilon$ неоднаковими. Практично кожен регіон має власні витоки, той або інший переважаючий тип конфліктів. Їх діагностика і подальше регулювання можливі лише 3 урахуванням всієї сукупності чинників, що визначають природу, джерела, стратегії поведінки учасників конфліктної взаємодії в даному регіоні. Українські регіони, які було сформовані в різні історичні часи, у складі різних держав, мають значні відмінності між собою за етнічним складом населення, рівнем урбанізації. До цих об'єктивних складових відмінностей додаються відмінності соціоментального характеру, які в умовах геополітичної невизначеності української держави мають тенденцію до загострення.

Виділення регіонального рівня чинників, що впливають на соціальну напруженість, припускає уточнення поняття «регіон». Проясненню цього поняття додавалися немало дискусій, акцентуючи увагу то на проблемі проведення просторових або адміністративних меж і позиціонування регіонів по відношенню один до одного, то на фіксації соціальних відмінностей. Дослідниками критерієм для «регіоналізації» бралися за визначені сукупності соціально-економічних ознак, соціально-політичних, електоральних, соціокультурних.

Проблема визначення поняття регіону, його полісемантичність зумовлена складністю i багатоаспектністю цього явища. $\mathrm{y}$ наукових дослідженнях принципи виокремлення чи «уявлення» регіону досить багатоманітні і практично не вичерпні. Здебільшого регіон виступає як суто умовна конструкція, зміст якої визначається тими завданнями, що їх ставить перед собою дослідник. Такого роду об'єкти дослідження припускають 
системний підхід, який включає різні аспекти і рівні його аналізу. У суспільних науках існує немало підходів до визначення «регіону». Основні ознаки, що характеризують поняття «регіон»: комплексність, цілісність, спеціалізація, керованість, тобто наявністю політико-адміністративних органів управління. У соціологічній літературі регіон розглядається, перш за все, як простір певної соціальної структури, організації влади і культурних традицій, що дає підстави соціологам говорити про територіально диференційоване об'єднання людей [100, с. 94].

Однозначного визначення терміна «регіон» суспільними науками досі не знайдено, тому доцільно навести декілька підходів до його розуміння. Перш за все, це цілісне економіко-територіальне утворення, котре складається 3 дрібніших соціально-економічних підсистем. Зарубіжний досвід свідчить, що територіальні диспропорції мають місце практично в усіх країнах. Крім того, досвід країн, які пройшли трансформацію соціальних систем, показує, що збільшення диспропорцій соціального розвитку є об'єктивним процесом.

Синтезуючи різні підходи, Е. Маркузе визначає регіон як «історично еволюціонуючу, компактну територіальну спільноту, яка містить в собі фізичне оточення, соціоекономічні, політичне та культурне середовище, а також просторову структуру, яка відрізняється від інших регіонів і територіальних одиниць, таких як місто або нація» $[11$, с. 7 , с. 251]. У рамках культурного спрямування Ф. Бродель трактував регіон як особливий «світ» 3 притаманним тільки йому менталітетом, способом мислення, традиціями, світоглядом i світовідчуттям. Близьким за змістом є визначення регіону М. Лернера - це єдність людей і місць, природних умов, етнічних груп, економіки, історії, характеру мислення і способу життя [6]. На думку Л. Олеха, «регіон визначається як самодостатній соціальний організм, що знаходиться в єдності 3 середовищем, що володіє фізико-географічними, культурно-цивілізаційними, економічними, етнічно-історичними, політико-адміністративними і правовими властивостями i виступає засобом формування i функціонування певної федерації» [8, с. 124].

Дослідник Ю. Запрудский виділяє наступні регіональні особливості:

- клімат, ландшафт, природні ресурси, які істотно впливають на умови життя населення;

- етнополітичні, культурно-історичні, релігійні, демографічні та ін. характеристики, що мають на даний момент значення об'єктивних чинників життєдіяльності населення, місця існування людей і основи формування стійких традицій і правил поведінки;

- стан економіки, наявність і ступінь кваліфікації необхідної робочої сили, специфіка соціальної структури, динаміка суспільних відносин, загальний рівень освіти і культури населення [3, с. 28]. 
Видно, що регіональний рівень представлений набором економічних, соціальних, політико-інституційних, культурних, конфесійних, екологічних, демографічних, історичних, етнічних, правових та ін. чинників, кожний $з$ яких виконує свою роль і вносить свій внесок у формуванні самобутності регіону. Тому відзначається полісемантичність поняття «регіон», зміст якого залежить від відображення конкретного зрізу життя.

Заслуговує уваги визначення І. Баджа та К. Ньютона, де «регіон»- це територія, яка $є$ реальною спільністю 3 географічного погляду, або така територіальна спільність, де існує спадкоємність і чиє населення поділяє певні загальні цінності та прагне зберегти і розвинути свою самобутність 3 метою стимулювати культурний, економічний та соціальний прогрес» [9, с. 124].

Таким чином, ключовими індикаторами поняття «регіон» $є$ певна територія, яка географічно виокремлюється зі складу загальної території країни; населення, яке проживає на цій території i має певні спільні особливі характеристики щодо решти населення цієї країни. Третім індикатором, виходячи 3 різних положень, повинна бути самоідентифікація або самоусвідомлення наявності в цієї групи людей певних особливостей, які відрізняють їх від загалу. Цей індикатор передбачає врахування пріоритету регіональної самоідентифікації над загальнонаціональною.

Як бачимо, сучасне розуміння «регіону» орієнтоване на його максимальну комплексність і цілісність, на повне врахування всіх його складових - природних, соціальних, економічних, політичних, з одного боку, i на визначення його своєрідності та унікальності - 3 другого. Така ситуація породжує низку методологічних питань і проблем: кожен компонент, кожний чинник регіоналізації має свою природу i свої закономірності щодо просторового розподілу.

Потрібно визнати, що всі рівні чинників впливають на інтереси та потреби великих мас людей, які складають «кістяк» або модель регіону. У центрі його завжди знаходяться певні епіцентри незадоволеності великих мас людей. Соціальна напруженість виникає від усвідомлення людьми своїх обмежених прав і інтересів (перш за все, деприваційна парадигма). Тут велику роль грають 3MI, за допомогою яких політичні і комунікаційні актори формують певну думку, артикулюють ідеї стосовно прав, інтересів суспільства. Це можуть бути ідеї історичної несправедливості щодо обмежених інтересів. Але головною причиною подібних дій виступають, як правило, економічні інтереси. Причому, соціально-політична напруженість має в основі незадоволені базові потреби людей.

Регіональність - багаторівнева категорія так само, як багаторівневою $\epsilon$ вся життєдіяльність суспільства. На даний час таксономія регіонів у вітчизняній регіональній економіці ще не розроблена. «Регіонами» нині називають і групи 
областей (Карпатський регіон, Донбас і т. д.), області (Одеський регіон та ін.), групи адміністративних районів (Придунайський регіон) тощо.

Кожна країна чи суспільство має 3 цього приводу свої особливості. Не виняток, а точніше чітку і контрастну регіональну диференційованість проявляє і Україна. Однак, в Україні є свої особливості. Визнано, що регіональні відмінності в Україні значно глибші, ніж у країнах Європи і набувають рис цивілізаційного характеру. Тут регіональні ідентичності сформувалися раніше, ніж виникла держава. Безліч відповідних комплексних досліджень вказують, зокрема, на дихотомічність регіональних ідентичностей Заходу та Сходу, особливо на ідеологічному, політичному, мовному рівнях, де виявляються елементи соціального відчуження у взаємосприйнятті. Та суттєвішим $\epsilon$ взаємозумовленість регіональних і політичних ідентичностей.

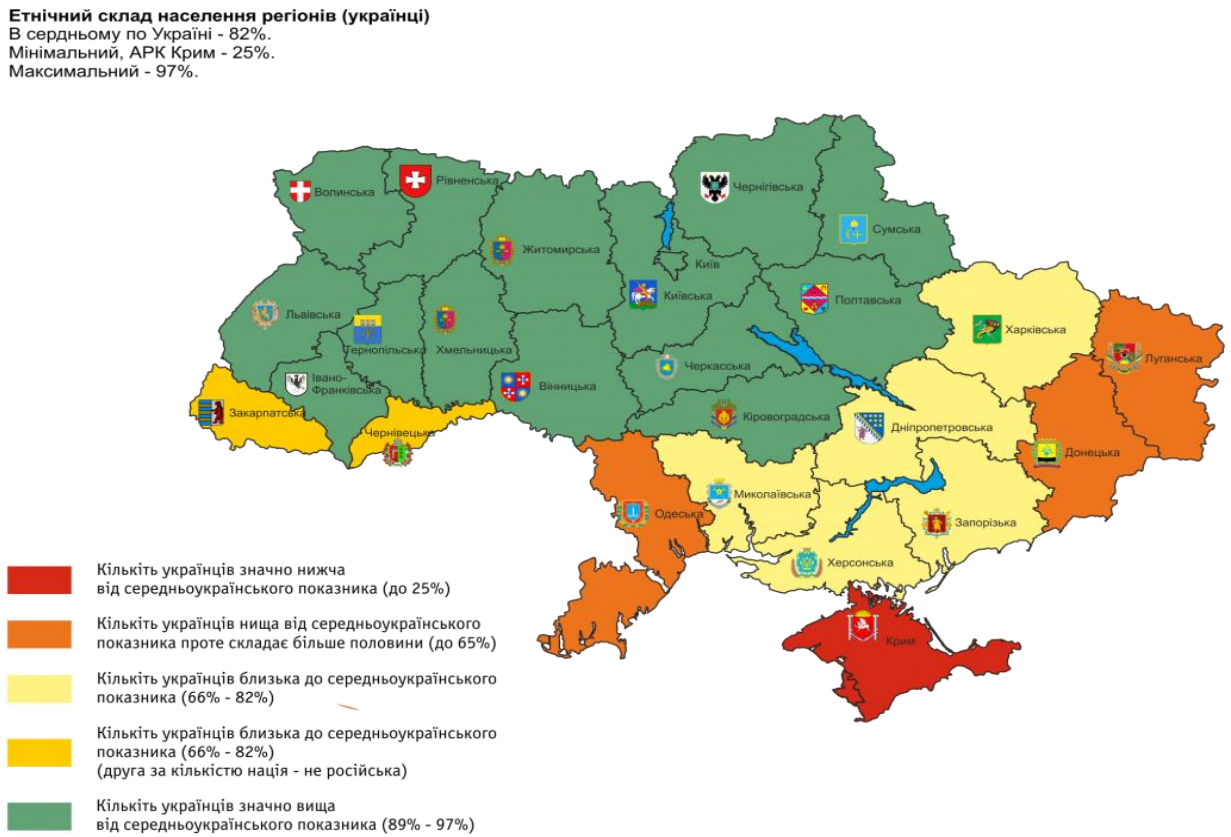

Мал. 1. Національний склад населення регіонів України (Інститут громадянського суспільства)

3 усіх комплексних досліджень та підходів найбільш прийнятним та, в кінцевому рахунку результативним 3 точки зору валідності, зокрема до застосування вивчення соціальної напруженості, став суспільно-політичний (електоральний) підхід до вияву регіональних особливостей в Україні. Ключовим для диференціації суспільно-політичного електорального простору стало поняття «регіональна ідентичність». Не заглиблюючись у сутність різноманітних варіацій його трактувань, можна сказати, що це «усвідомлення культурної, історичної, етнічної тощо окремішності населення певного регіону» 


\section{РЕГІОНАЛІЗАЦІЯ УКРАЇНИ У КОНТЕКСТІ СОЦІОЛОГІЧНОГО ДОСЛІДЖЕННЯ СОЦІАЛЬНОЇ НАПРУЖЕНОСТІ}

[2, с. 44]. Основними параметрами регіональної ідентичності, в рамках яких розгортається незбіг і полярність інтересів та цінностей, на базі багаторічного дослідницького досвіду соціологами визначено: ступінь лояльності до державної влади, зовнішньополітичні орієнтації; мовні пріоритети, конфесійні уподобання; домінанти історичної пам'яті, питома вага «лівих» чи «правих» політичних настроїв [5, с. 287-305]. Структурування електорального простору відбувалося переважно на ідеологічній основі: «правий» Захід та «ліві» Схід, Південь і Центр країни. Більшість дослідників відокремлюють політичну культуру Правобережжя і Лівобережжя. Далі структурування електорального простору України супроводжувалося за регіональними елітами як носіями регіональних ідентичностей, що дало підстави дослідникам стверджувати про зародки нової осі територіальної диференціації суспільно-політичних (електоральних) переваг - «прозахідна/ проросійська» орієнтація.

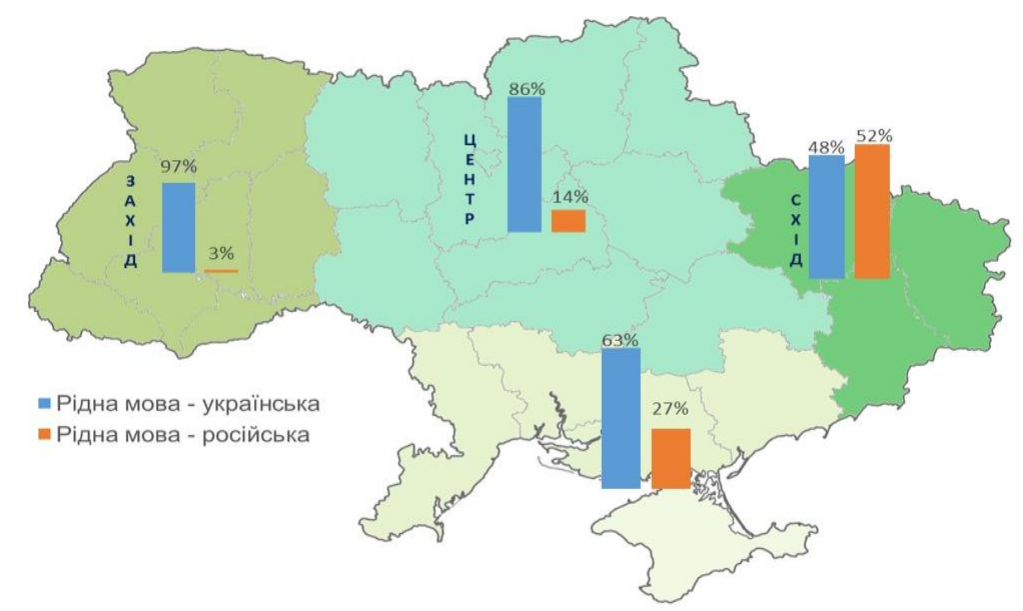

Мал. 2. Поширення української та російської мов в регіонах України (КМІС, 2017)

На сьогодні відбулася агрегація та артикуляція політичних інтересів частини суспільства у нехарактерний для представницької демократії спосіб: у форматі «майдан - влада», а не «влада - опозиція», що свідчить про глибоку кризу політичної системи країни та створює передумови територіального розмежування. 


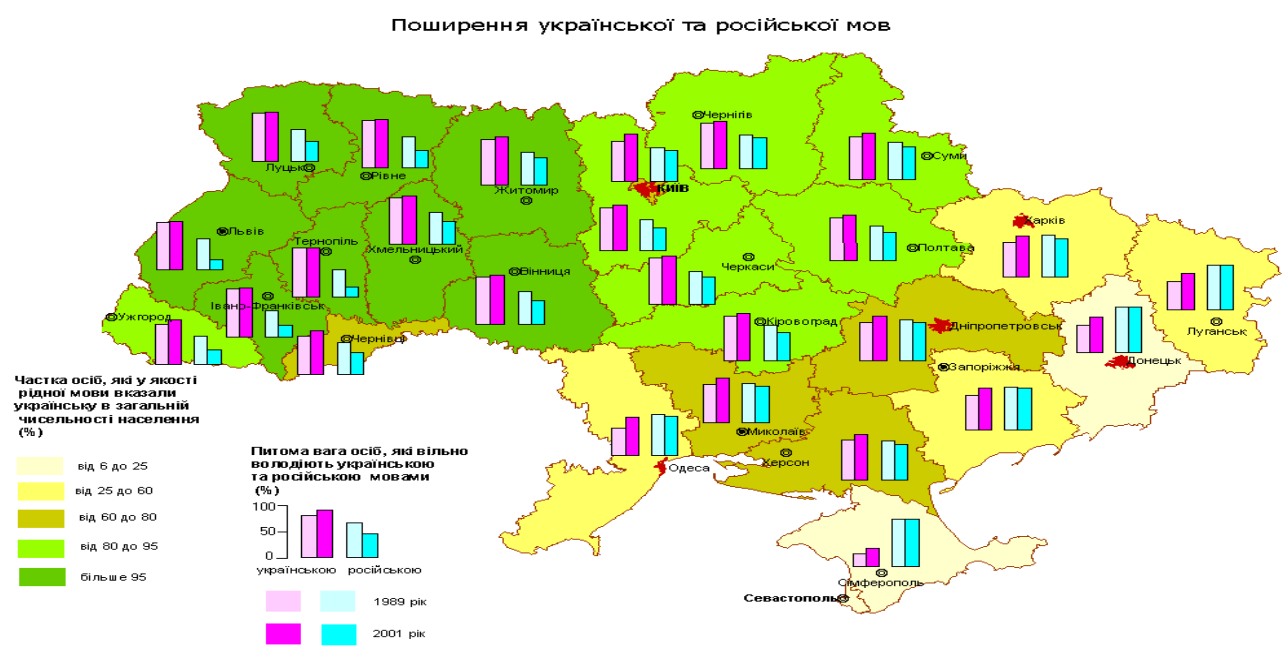

Мал. 3. Поширення української та російської мов у регіонах України (Державний комітет статистики України)

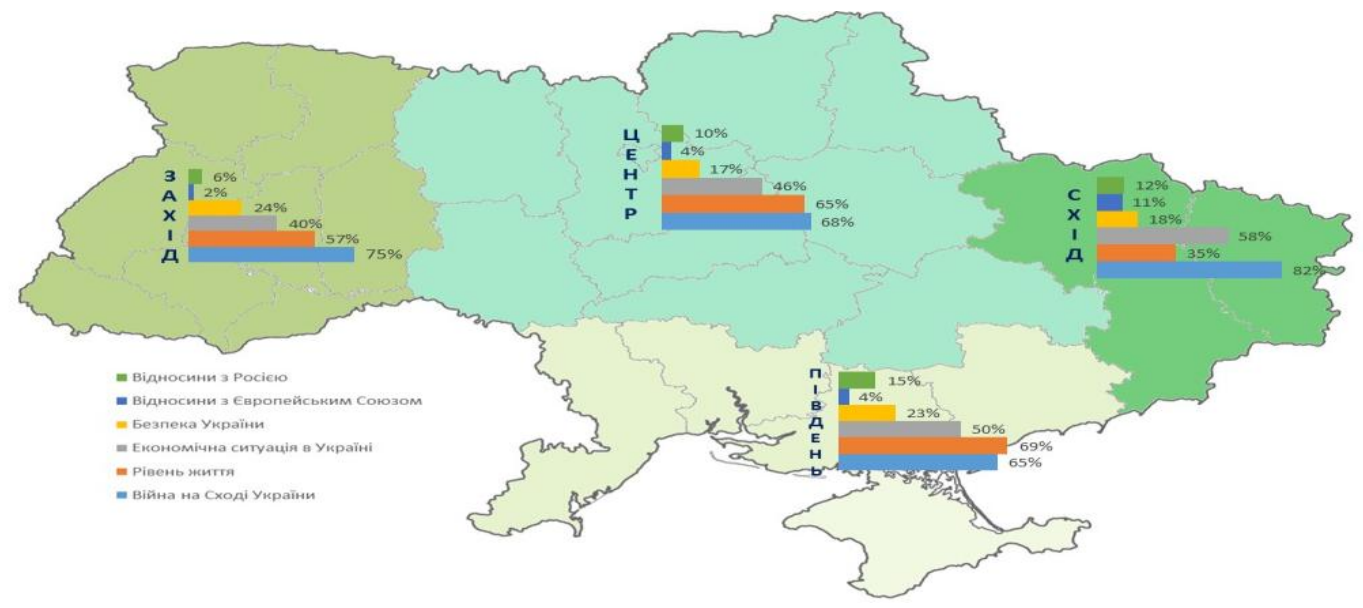

Мал. 4. Міжрегіональні відмінності соціальної напруженості в українському суспільстві (КМІС, 2017)

Отже, ціннісною основою кожного регіону України $є$ власний соціокультурний код, який можна розглядати як концентрацію природногеографічних, геополітичних, геоекономічних, історичних, культурних та ін. ознак. Його вплив на суспільно-політичні симпатії виявляється визначальним. Перенесення постулатів теорії електоральної географії на реалії України свідчить про те, що всі перелічені фактори і ефекти тією чи іншою мірою мають дію. Тому, вказані електоральні цикли виявили диференціацію суспільно-політичних переваг українців за регіональною ознакою. 
Грунтуючись на різних дослідженнях та відповідному науковому аналізі електоральних вподобань виборців дослідники за власною логікою виділяли різні регіональні структури як за кількістю, так і за включеністю тієї чи іншої області. Доволі популярним, зокрема, є поділ на чотири основні макрорегіони. Для співробітників Національного інституту стратегічних досліджень Ю. Каплана та С. Янішевського - це Захід, Схід, Центр та Південь [4]. Л. Нагорна виділяє Західний, Центральний, Південно-Східний регіони та Автономну Республіку Крим [7, с. 206]. У вітчизняному медіа-дискурсі регіонами називають області. За результатами аналізу проведеного О. Вишняком, виділено п'ять типів політичних регіонів України: Донбас та Крим (Донецька та Луганська області, АР Крим, м. Севастополь); інші південносхідні області (Дніпропетровська, Запорізька, Миколаївська, Одеська, Харківська, Херсонська області); перехідний регіон Північного Сходу та Кіровоградська область (Житомирська, Кіровоградська, Полтавська, Сумська та Чернігівська області); Центральна Україна (м. Київ, Вінницька, Київська, Хмельницька, Черкаська області); Західна Україна (Волинська, Закарпатська, Івано-Франківська, Львівська, Рівненська, Тернопільська, Чернівецька області) $[1$, c. 336].

Як бачимо сама ж наукова процедура регіоналізації українського суспільства не $\epsilon$ загальноприйнятою та часом містить неабиякі суперечності. В системі виокремлення регіонів України існує (на що ми вказували) багато т. зв. «змінних», котрі не дозволяють строго виокремити ті чи інші регіони, навіть не стільки 3 причин соціальної обумовленості кожного із них, скільки 3 науково-дослідницьких інтересів і векторів того чи ін. наукового напряму. Здійснений аналіз спеціальної літератури, дослідницька практика засвідчили, що альтернативним розв'язанням даної проблеми $є$ широко застосовувана практика одинично-адміністративної (пообласної) регіоналізації у початкових етапах дослідження та аналізу. Це $\epsilon$ виправданим для багатьох типів та різновидів дослідження, перш за все, електоральних, суспільно-політичних, соціально-економічний, соціально-правових тощо, котрі виявляють адміністрування як один із важелів розвитку кожного регіону-області.

Висновок. Дане питання має кілька сторін, тому одну 3 них визначає об'єкт дослідження як інструмент, котрий допомагає виявити особливості дії зовнішніх чинників у різних регіонах, то у методиці закладаються можливості визначення особливостей розвитку регіонів, а отже, неоднозначність чинників, що визначають $\mathrm{CH}$ в регіонах. Вивчення соціальної напруженості потребує $\mathrm{i}$ ситуаційного підходу у специфіці окремого регіону, за яким при аналізі необхідно враховувати історичний, соціокультурний розвиток певного регіону, $\mathrm{i}$ перш за все, враховувати соціально-економічні, суспільно-політичні та ін. показники, що виявляється у кількісних процедурах аналізу даних. Це, 
зокрема уможливлюється при застосуванні з точки зору дослідницької практики базових, політичних досліджень методики «соціальної карти». Процедурно, це виявляється у застосуванні т. зв. соціального картографування («соціальна карта») регіону - просторового розподілу системи комплексних соціальних показників (даних): системи статистичних показників різно-галузевого характеру, що ідентифікують окремий регіон (область, район, місто): демографічна, соціально-економічна, суспільно-політична та ін. характеристика певного регіону, його соціокультурні, історичні та геополітичні (що на сьогодні актуалізує) особливості та специфіка його розвитку.

\section{Список використаних джерел:}

1. Вишняк О. Політична типологія регіонів України: динаміка та фактори змін / О. Вишняк // Українське суспільство 1992-2008. Соціологічний моніторинг / за ред. В. Ворони, М. Шульги. - Київ : Ін-т соціол. НАН України, 2008. - С. 331-342.

2. Головаха Е. И. Потенциал протеста украинского общества / Е. И. Головаха, Н. В. Панина // Социологические исследования. - 1999. - № 10. C. $31-40$.

3. Запрудский Ю. Г. Региональные конфликты: понятие и специфика Северного Кавказа / Ю.Г.Запрудский // Этнические конфликты и их урегулирование : сб. науч. ст. - Москва ; Ставрополь, 2002. - С. 28.

4. Каплан Ю. Чинники міжелекторального стирання граней (на матеріалах соціологічних досліджень) [Електронний ресурс] : Аналітична записка відділу стратегій розвитку політичної системи Національного інституту стратегічних досліджень / Ю. Каплан, С. Янішевський. - Режим доступу: http://www.niss.gov.ua/Monitor/May2009/9.htm. - Назва 3 екрану. - Дата звернення: 17.02.2018.

5. Куценко С. В. Феномен виборчих аксіотехнологій: сутність і практики застосування в електоральних кампаніях в Україні / Є. В. Куценко // Наукові записки ІПіЕНД. - 2013. - Вип. 2 (70). - С. 287-305.

6. Лернер М. Развитие цивилизации в Америке / М. Лернер. - Москва, 1992. -264 c.

7. Нагорна Л. П. Регіональна ідентичність: український контекст / Л. П. Нагорна. - Київ : ІПіЕНД ім. І. Ф. Кураса НАН України, 2008. - 405 с.

8. Олех Л. Г. Реформи і регіоналізм в Росії : навч. посіб. / Л. Г. Олех // 2000. - C. 124.

9. Романюк А. Порівняльний аналіз політичних інститутів країн Західної Європи : монографія / А. Романюк. - Львів : Видавн. центр ЛНУ ім. Івана Франка, 2007. - 391 с. 
10. Стегний А. Региональный фактор развития политической культуры населения Украины / А. Стегний // Социология: теория, методы, маркетинг. 2005. - № 3. - C. 94-122.

11. Markusen A. Regions: Economics and Politics of Territory / A. Markusen. - Rowman and Littlefield Publishers, 1987. - 251 p.

\section{References:}

1. Vyshniak, O. (2008). The Political Typology of Ukrainian Regions: Dynamics and Factors of Change. V: Ukrainian Society 1992-2008. Sociological monitoring. Kyiv : Institute of Sociology NAS of Ukraine, pp. 331-342.

2. Golovakha, E.I. (1999). Protest Potential of Ukrainian Society. Sotciologicheskie issledovaniia [Sociological Researches], no. 10, pp. 31-40.

3. Zaprodsky, Iu.G. (2002). Regional conflicts: the concept and specificity of the North Caucasus. V: Ethnic conflicts and their settlement: collection of scientific papers. Moscow, Stavropol, P. 28.

4. Kaplan, Yu. Factors of intervertebral erosion of faces (on materials of sociological research). V: An analytical note of the department of strategies for the development of the political system of the National Institute for Strategic Studies. [online] Available at : http://www.niss.gov.ua/Monitor/May2009/9.htm. [Accessed 17 February 2018]. Title from the screen.

5. Kutsenko, Ye.V. (2013). The Phenomenon of Electoral Axiom Technologies: The Essence and Practice of Electoral Campaigns in Ukraine. Naukovi zapysky Insytutu politychnykh sh utnohrafichnykh zhoslidzhen im. I. F. Kurasa [Scientific notes of Kuras Institute of Political and Ethnic Studies of the National Academy of Sciences of Ukraine], issue 2 (70), pp. 287-305.

6. Lerner, M. (1992). Development of civilization in America. Moscow.

7. Nagorna, L.P. (2008). Regional identity: Ukrainian context. Kyiv : Kuras Institute of Political and Ethnic Studies of the National Academy of Sciences of Ukraine.

8. Olekh, L.H. (2000). Reforms and regionalism in Russia: a textbook.

9. Romanyuk, A. (2007). Comparative Analysis of Political Institutions in Western Europe: Monography. Lviv: Publishing Center of Ivan Franko National University of LNU.

10. Stegnii, A. (2005). Regional factor of development of political culture of Ukrainian population. Sotciologiia: teoriia, metody, marketing [Sociology: theory, methods, marketing], no. 3, pp. 94-122.

11. Markusen, A. (1987). Regions: Economics and Politics of Territory. Rowman and Littlefield Publishers.

() Сірий Є. В., 2018 